\title{
"Where the Shoe Pinches": Impediments to Successful Execution of Gender Quota Thresholds in Kenya
}

\author{
Hellen Kwamboka Kilelo \\ Department of Gender and Development Studies, \\ Moi University, Kenya. \\ Dr. Alice Kurgat \\ Department of Gender and Development Studies \\ Moi University, Kenya. \\ Dr. Charles Ochieng Ong'ondo \\ Department of Curriculum Instruction and Educational Media \\ Moi University, Kenya.
}

\begin{abstract}
The promulgation of the $\mathbf{2 0 1 0}$ Kenyan Constitution inspired me to carry out a research with the objective of identifying the impediments to the successful implementation of gender quotas. This study was carried out in the year 2018 after the second set of County Governments had settled in office. Specifically, I adopted a multiple case study design because I examined perspectives on the implementation of the gender quota threshold in two cases i.e. two Counties. Purposive sampling was used to arrive at the participants. Data for this research was generated using interviews, Focus Group Discussions, and document analysis and the data collected was analyzed thematically. The interviews were conducted with County Public Officers, MCAs and other stakeholders purposively selected in the two Counties and key stakeholders in Nairobi. The main findings to this study were as follows: recruitment mechanisms are riddled with male patronage and bias; there are structural barriers and exclusionary practices that deter successful implementation of gender quotas; there is limited funding for Gender Departments and Gender Committees in the Counties and there are social perceptions that hinder the effectiveness of the gender quota threshold. In conclusion, gender quotas require a perceptual shift. The following recommendations are given in this study: there is need to have incentives that will help promote gender quota thresholds, the need to have a sectoral approach to gender and a strategy for balancing between quantity and quality.
\end{abstract}

Keywords: Gender Quota thresholds, Member of County Assembly (MCA), County Executive Committee Member (CEC Member), County Executive, County Assembly

\section{INTRODUCTION}

Gender quota threshold in this study refers to a constitutional reform policy aimed at ensuring that not more than two thirds of either gender should be elected or appointed into office. The promulgation of the 2010 Kenyan Constitution ushered in a new political dispensation in Kenya with several gains more so in relation to gender. More opportunities were opened up for women both in political and public life thereby promoting gender equality (Domingo et al, 2016). In addition, Articles 10 and 27 promote equality, equity and non-discrimination amongst other values as national values. More specifically, Article 27 (3) states:

Women and men have the right to equal treatment, including the right to equal opportunities in political, economic, cultural and social spheres (p.40). 
During the 2013 Kenyan elections, 623 women vied for the post of County Ward Representative against 9,287 male contestants. Out of this, 85 women and 1365 men were voted giving a total of 1450 County Ward Representatives countrywide (Muiruri, 2013). In 2017, out of the 1450 County Wards, 96 women were elected which is a slight improvement compared with 2013 but this still falls short of the two third threshold (Oruko, 2017). Although there was progress compared to previous elections, the women elected are a paltry 6.6 percent of the total Members of County Assembly (MCAs) elected. This is what motivated me to carry out this study with an aim of understanding the impediments to the successful implementation of gender quota thresholds at the County Government level.

The definition of the gender quota threshold adopted in this study is the one found both in the Kenyan constitution and the County Government Act. In the Kenyan constitution, article 197 (1) states that

Not more than two thirds of the members of any County Assembly or County Executive Committee shall be of the same gender (p.121).

Article 175 (c) also states that:

No more than two thirds of the members of representative bodies in each County Government shall be of the same gender (p.108).

Article 81(b) also reiterates that:

Not more than two-thirds of the members of elective public bodies shall be of the same gender;

Under the bill of rights, we have article 27(8) which states that:

In addition to the measures contemplated in clause (6), the state shall take legislative and other measures to implement the principle that not more than two-thirds of the members of elective or appointive bodies shall be of the same gender.

The County Government Act 2012 clearly states in article 35 (2) that

The County Assembly shall not approve nominations for appointment to the executive committee that do not take into account not more than two thirds of either gender.

This study was conducted with the view of taking stock of the implementation of gender quotas and the challenges faced so far. This paper is divided into several parts. Firstly, I begin by discussing the academic context of the research followed by the methodology used and the findings. Finally, I give the conclusion of the work and this is followed by references.

\section{Academic Context}

This study is about gender quotas. According to Galitos (2018), generally, Quotas are a form of positive discrimination empowering groups historically marginalized from decision making (p.19).

In this context, quotas are viewed as a form of affirmative action aimed at helping the women to overcome the obstacles that deter them from entering into politics in the same manner as their male counterparts (Chen, 2010). According to Paxton and Hughes (2015),

A gender quota is a party or legislative rule requiring that women make up certain percentage of a candidate list, a parliamentary assembly, a committee or a government (p.333).

The ultimate goal of gender quotas is to increase the number of women elected to political office (Franceschet et al, 2009). For a long time, the problem has been that in most countries, 
women constitute over 50 percent of the population and yet are underrepresented as on average they hold 23.4 percent of parliamentary seats (www.quotaproject.org). The problem therefore is the underrepresentation of women in politics that demands the use of gender quotas. Although most governments and political parties strive to have at least 30 percent of women in parliament, the representation levels differ in different countries. Some countries have higher thresholds than others for example France and Senagal have a 50/50 gender threshold as compared to Albania that has a 30 percent threshold for Members of Parliament and 50 percent threshold for municipal council candidates (Gender Alliance for Development Centre, 2015; Toraasen, 2016).

Gender quotas represent fast track measures towards women's advancement as opposed to the incremental track model that stipulates that countries will achieve gender equality with time as they develop (Mejere, 2012). Besides, Nzomo (2012) contends that:

There is a positive correlation between socio-economic development and political representation (p.13).

Initially, it was generally agreed that women should at least constitute a third of those in decision-making positions in order to propel policies that are women friendly. However, in the year 2000, the Women's Environment and Development Organization (WEDO) advocated for a $50 / 50$ campaign to achieve gender balance. This is to date being supported by the United Nations (United Nations, 2016).

Many countries adopted gender quotas mainly as a result of the influence of the Beijing UN Fourth World Conference in 1995 (Chen, 2010) as a way of addressing the inequalities in women's involvement in politics. As a matter of fact, Dahlerup (1998) stated that there was a "quota fever" that was spreading round the world after this Conference.

Under women in power and decision-making, it was stated that women are still under represented in most levels of government and that although the target was to have 30 percent in positions of decision making, globally only 10 percent had made it to the legislature and a few ministerial positions. Countries committed themselves to ensure gender balance in the government bodies, public administration and the judiciary (ibid).

Sustainable Development Goal number 5, which was initially Millenium Development Goal number 3, aims at empowering women to participate in politics and public life amongst other goals. (The Sustainable Development Goals Report, 2016). Data on women participation at the local government level is limited. And this presents a knowledge gap. According to UNDP (2016),

Engendering African democracies through greater women's participation is part of the structural transformation necessary for achieving social equality and higher human development (p.77-78).

Worldwide, women's involvement in local governance with specific reference to decisionmaking groups is low (Banerjee-Hamadeh, 2000; Shamim and Kumari, 2002).And yet gender parity at all levels of government is important (Thomas, 2016). The participation of both men and women at the local level is important as it ensures that there is equity in the sharing of resources in as far as the budget is concerned and in the provision of all other services (United Nations Human Settlements Programme, 2008, UN Women, 2013). Braga and Scervini (2015) state that:

Equal participation of women in politics at all levels of government is essential not only to build and sustain democracy but also to enhance equality in other social dimensions (p.2). 
This study is premised on the fact that in order to influence policy and key decisions, there is need to have women on board in the decision-making process (Ibid). This includes the lobbying for gender sensitive policies. Participation of women in local governance also serves as a springboard to participation in national governance (National Democratic Institute, 2010; White and Mariani, 2015).

There are several debates that are associated with gender quotas. Firstly, gender quota thresholds have succeeded in increasing women's participation in politics substantially for example in Rwanda, Bolivia, South Africa, Senegal and Sweden amongst others (Brody et al, 2016). However, increasing the representation of women in governance does not necessarily mean that women's interests have been fully integrated as more often than not they bring up the agendas of their ethnic groups and political parties to parliament (United Nations, 2006). This could be as a result of their lack of awareness on the important issues that they should present, lack of alliances and other critical networks that would support them and lack of resources amongst others (ibid). Besides, other women are reluctant to concentrate on women's issues because they risk not being considered serious politicians (Brody, 2009).

Secondly, some studies have shown that quotas act as a ceiling in the sense that people are not able to elect more women than what has been stipulated by the quota e.g in Bangladesh and Jordan. However, Rwanda has surpassed its quota threshold of 30 percent and now has a women's representation of 63.7 percent which is the highest in the world (www.quotaproject.org). This is a clear indication that the success of quotas is dependent on the country and the conditions under which the quota is implemented.

Thirdly, others have argued that gender quotas are discriminatory in nature because they prioritize on sex other than one's political beliefs and other 'serious issues' (Brody et al, 2016). However, other scholars view quotas as an affirmative action that is meant to increase women's representation because for a long time they have been left out yet sustainable development requires their participation in political and public office (The Sustainable Development Goals Report, 2016).

In a nutshell, sustainable development can only be achieved when both men and women are integrated in the political and socio-economic development. This study therefore looked at impediments to the implementation of the gender quota threshold from a development perspective.

\section{The Theory of Political Representation}

\section{THEORETICAL FRAMEWORK}

Hanna Pitkin, in her work The Concept of Representation sets the foundation for the theories of representation. Pitkin (1967) distinguishes between four main forms of representation namely: formalistic representation, symbolic representation, descriptive representation and substantive representation. Although these different dimensions are perceived by the author as essential parts of a whole, many scholars ignore certain forms and only use one or two based on those that they feel are important or on those that data is readily available (Kurebwa, 2015). In this study the emphasis was on all the three forms of representation. This is because my study looks beyond the numbers of women elected or appointed in a bid to interrogate the challenges that they face in the context of the County governments. These facets of political representation examine the impact of gender quotas thereby moving the debate beyond the issue of numbers (Dahlerup, 2010). 


\section{Formalistic Representation}

This represents institutional engagements that precede representation. Formalistic representation comprises two variants i.e authorization and accountability (Pitkin, 1967). Authorization involves the process through which a representative is brought to power e.g through elections whereas accountability is the process of either punishing the representative by voting him or her out or voting him/her in depending on how responsive he/she is to the needs of those who are being represented (ibid).

\section{Descriptive}

Descriptive representation encompasses questions to do with the effect of quotas on the women elected and their social background in terms of ethnicity, sex, age and other demographic characteristics (Dahlerup, 2010; Franceschet et al 2009). This implies that one would have to count the number of women in office and in the same vein scrutinize these women in terms of their education, occupation, age, political experience and family connections compared to those not elected through quotas without looking at what they are saying or doing. According to Pitkin (1967), both descriptive and symbolic representation can also be viewed as "standing for" representation.

The relevance of descriptive representation to this study is the fact that first and foremost, gender quotas are meant to increase descriptive representation as women in Kenya have been underrepresented for many years. However, it was plausible to go beyond numerical representation and flesh out the symbolic and substantive depictions of women in the County governments and examine the challenges associated with this. This is because if one was to stop at descriptive representation, the change may be construed to be cosmetic.

\section{Symbolic}

Symbolic representation is concerned about the conceptions or perceptions of the voters' on the people they have elected (Franceschet et al 2009; Dahlerup, 2010). Pitkin (1967) compares women to flags that represent a nation and underscores that what counts is not the flag but the power it has to evoke attitudes or feelings. In that sense then, symbolic representation is not about who these women are or what they do but rather how they are perceived by the people they represent (Kurebwa, 2015). In other words, this has to do with the public attitudes over these female constituents and how these quotas help to break traditional barriers between men and women. As earlier mentioned, symbolic and descriptive representation are also referred to as "standing for" representation as opposed to "acting for" representation that characterizes substantive representation.

\section{Substantive}

Pitkin (1967) defines substantive representation as: Acting in the interests of the represented in a manner responsive to them (p.209).

Substantive representation is premised on the ability of the elected to perform effectively and represent the interests of the electorate in terms of policy outcomes and agenda building (ibid). In other words it involves an examination of how quotas influence the kinds of policies proposed and passed and generally the priorities of women elected through quotas. Pitkin considers this to be the most important dimension of representation and describes it as the "acting for" representation.

Substantive representation was particularly important for this study as I examined the blockades to successful implementation of gender quotas across the three forms of representation. 


\section{METHODOLOGY}

The research approach to the inquiry that was adopted in this study was the qualitative approach. This approach is keen on understanding and exploring meanings that respondents attach to a human or social problem (Cresswell, 2014). For this study, qualitative approach was the most appropriate for this study because I was able to get emic perspectives on the barriers to successful implementation in a subjective environment (Savin-Baden and Major, 2013). This study adopted a case study method. Specifically, I adopted a multiple case study design because I examined perspectives on the impediments to successful execution of the gender quota threshold in two cases i.e. two Counties. Purposive sampling was used to arrive at the participants. In total, 22 people were interviewed and 5 Focus Group Discussions were carried out with a total of 31 people. In total, total sample size was 53 participants.

Data for this research was generated using interviews, Focus Group Discussions, and document analysis and the data collected was analyzed thematically. The interviews were conducted with County Public Officers, Members of County Assembly and other stakeholders purposively selected in the two Counties and key stakeholders in the gender discourse in Nairobi.

\section{FINDINGS AND DISCUSSION}

The main findings to this study were as follows: recruitment mechanisms are riddled with male patronage and bias; there are structural barriers and exclusionary practices that deter successful implementation of gender quotas; there is limited funding for Gender Departments and Gender Committees in the Counties and there are social perceptions that hinder the effectiveness of the gender quota threshold.

\section{Recruitment mechanisms are riddled with male patronage and bias.}

Political parties were the main culprits in the nomination process. As a matter of fact, they are considered as gatekeepers in the election and nomination process. To begin with, the recruitment of people to a political party is based on "ethnic balkanization and because tribes are by nature patriarchal, women are excluded from that equation". This means that most Political Parties are mainly composed of a few dominant ethnic groups thereby reducing them to ethnic enclaves.

As stated by the participants, there was a lot of meddling in the political parties affairs. The Gender Top- Up lists were used for tokenism whereby friends, relatives and girlfriends amongst others were rewarded through being included in these lists. As one interviewee said, these nominations are based on "a romantic relationship".

One participant felt that in some instances, men "nominate women who are either weak politically or who have some baggage of some sought, so they won't be expressive enough and then it is used against them to show why there is no justification for more women".

In the case of appointments in the County Assembly, it was stated that the women were given 'soft' ministries such as Ministry of Gender, Youth and Sports, Agriculture and Tourism amongst others. Ironically, in one of the Counties that I visited, the CEC Member for Gender was a man whereas the CEC Member for Finance was a woman. In this same County, the Deputy Governor was a woman. This reveals that these appointments are based on individual Governors and this could be determined by their perspectives on gender matters or as one said, this can be done to appease the women voters. However, the view among the electorate is that the two-thirds is for men whereas the third is for women. In both Counties, appointments were based on this view. This could be as a result of the fact that no one would really want to change the status quo. O'Brien (2017) warns that political parties are unlikely to choose 
leaders, male or female who are likely to move them far beyond the status quo and therefore even female leaders are unlikely to go against the grain.

Political Parties prepared the nomination lists which they forward to IEBC then it is forwarded to the County Assembly. The Speaker and the Clerk then ensure that everything is carried out according to the law. The County Assembly Board deals with all other recruitments associated with the Assembly. In as far as committees are concerned, MCAs had the opportunity to choose two sectoral committees and one select committee. I had an opportunity to carry out an FGD with the Gender Committees in both Counties. One was headed by a man while the other one was headed by a woman after they were both voted in. In the Committee that was headed by a male MCA, one female MCA vented her frustrations as she really wanted to be the Chair but she missed narrowly after even the female MCAs voted for the man.

In both Committees, there was evidence of gender sensitive bills and motions that had been passed especially by those who were serving their second term in the County Assembly. In one County, there was a bill on a revolving fund for women, youth and people with disabilities and a motion on motivating the boy child. In another County, there was a motion on tools that will be used in Monitoring and Evaluation during public participation, a motion on gender based violence, a motion on the increment of ECDE schools and teachers, a motion urging the County Governor to contract pro borno lawyers to deal with cases of abuse and injustice in the County, a motion on the need to make the Level 5 hospital in the County a one stop shop for victims of gender violence where one can get medical services, counseling, P3 and justice in the court amongst others.

\section{Structural barriers and exclusionary practices deter successful implementation of gender quotas.}

Despite the presence of gender-progressive legislation in the Kenyan constitution, partriachy was one of the key pronounced issues that was raised as being a major obstacle to the implementation of the gender quota threshold. Patriarchy is manifested both at the institutional level and at the individual level. Kenya just like many other countries is patriarchal in nature. Patriarchy is oppressive and considers women as being subordinate to men.

These patriarchal customs include norms related to one's age, FGM status and marital status amongst others. For example, In one of the County's, women tend to get circumcised in order to conform to culture and find acceptance in the community. Men whose wives have not been circumcised and are planning to vie will be teased by other men and told that they have a child in the house. The men will thereafter state that they cannot be led by a child and this will ruin the woman's opportunity for leadership. This is mainly a factor in the rural areas but due to modernization, perceptions are changing. Women who would love to take advantage of the gender quota threshold also face other challenges. For example, if a woman is vying and she is single she will be victimized based on the fact that she has no ability to relate with a man and that's why she is not married. Besides, people will keep wondering what happens if she gets married to a man from a different community. If she is married, she will be told that once she gets into politics she will leave her husband for another man. If she is widowed, she may be told that she killed her husband and may not go through. This reflects the fact that women are judged harshly whenever they want to get into politics.

However, it was ironical that although the participants from one county outlined various contextual conditions that hinder women, the reality is that historically and against all odds, as one participant stated, 'Kalenjins have consistently produced the largest number of elected 
parliamentarian women' and therefore this reality contradicts the views presented. Patriarchy is one of the major factors that determine whether women are able to take advantage of quota provisions (Nazneen, 2018).

The nature of patriarchal norms differs in different provinces and regions even within the same country and therefore, in regions where patriarchy is less restrictive in as far as women's engagement in the "masculine" arena is concerned, then more women will benefit from the quota provision (ibid). However, using this kind of criteria to judge women is exclusionary in nature and does not promote the spirit behind gender quota thresholds.

One thing comes out clearly in this study. This is the fact that in this context, the women may have multiple hurdles to cross in as far as social and cultural norms are concerned, but those who succeed end up being elected. In order to sustain these positions, one participant stated that "they have to exhibit masculine traits or they have to be masculine". On the contrary, in South Asia, women depict a 'feminine altruism' and avoid confrontation or opposition to male authorities (Nazneen, 2018). However, the underlying factor is that women's pursuit for political representation is judged based on family and more specifically relationship with a husband. Whether one is married or not has far reaching effects.

\section{There is limited funding for Gender Departments and Gender Committees in the Counties}

From the interviews carried out among County Executive and County Assembly officers, it was clear that there was scarce funding for the Gender Department and for the Gender Committees. One interviewee remarked that "Am actually an officer of gender with zero gender budget. When the budgeting process starts, there is usually money but when it's getting fine-tuned and getting to the Assembly, the funds now disappear". At the County level, in both counties, the Gender Departments were not well funded together with the Gender Committees in the County Assemblies because people felt that there were more urgent issues to address such as roads, schools and hospitals amongst others. Gender issues are viewed as being synonymous with women issues.

As a matter of fact, another participant said “There are women's issues but women's issues are everybody's issues. Yes they are development issues. Maybe things like menstruation and other issues but they are still development issues".

Although the Counties are supposed to hire Gender Officers who are based at the Sub-County level, in both Counties, these officers are only engaged on part-time basis subject to availability of funding. Due to inadequate funding, sensitization programmes were not carried out as they should for example by the County Assembly Board.

At the the individual level, the women themselves lack finances to carry out campaigns and give in fundraisings amongst others. Campaigns require that one is able to hire transport, pay the campaigning team, give hand-outs and entertainment amongst others (Wang and Yoon, 2018). In addition, the National Gender and Equality Commission (NGEC) also lacked the resources to carry out gender audits in all the Counties.

There are social perceptions that hinder the effectiveness of the gender quota threshold Gender quotas, focus on reversing the trends in as far as participation in governance is concerned. However, there are several social perceptions that hinder the effectiveness of gender quotas. Firstly, there are misconceptions associated with being a Women's Representative and a stigma related to Nominated MCAs. The men used the Women's Rep seat 
to dissuade the electorate against voting for women in other designated seats claiming that they had their own seat. This is an unintended consequence of the gender quota legislation in Kenya. Besides, one participant, a former Women's Representative stated that "When they are counting leadership positions they count this one of women as "saucer". This implies that this comes as an afterthought.

Nominated MCAs were also not respected and given the same honor as their elected counterparts. Most of the nominated MCAs were women who were told that they did not represent anyone in the Assembly. This accusation was also leveled on Women Representatives too of whom people referred to as "County MP" which was considered a more inclusive and friendlier term. Apart from that, female MCAs who had been nominated through the gender to-up structure were termed as 'Bonga points' which refers to points that one earns through using a certain mobile network over time (Domingo et al, 2016). Wang and Yoon (2018) also found that in both Uganda and Tanzania, quota MPs did not receive the equal respect to that of elected MPs. Besides, in Uganda, quota MPs risk being termed as second-rate politicians (ibid).

Secondly there was the perception that women should not vie for geographical seats because they will be nominated for gender top up positions. The women were therefore asked to leave these seats to the men. The County Public Service Board also experienced challenges in that the citizenry preferred men to women for certain positions such as Ward Representative and Directors as they felt that the women did not have the ability to handle these positions.

It is clear that the gender quota legislation draws different perspectives but the implementation is being done begrudgingly because it challenges the norm in as far as the power structures are concerned and it involves the restructuring of power.

From the findings, it was clear that institutions that should enforce the gender quota legislation are toothless. These include the Independent Electoral and Boundaries Commission (IEBC) and the Registrar of Political parties. Besides, the current Registrar of Political Parties does not enjoy security of tenure. Domingo et al (2016) notes that for a constitutional legislation to shape the political, economic and social engagement, there needs to be an adequate organizational, institutional and bureaucratic capability for enforcement and implementation.

\section{CONCLUSIONS}

Domingo et al (2016) points out that legal change over time is interpreted as a technical change other than a political instrument. Therefore, to protect legal gains like the gender quota threshold one, there is need to have strategic and political action that complements the technical bit. In addition, there is need to engage and network with different actors in order to protect the constitutional gains made so far (ibid). Therefore, constitutional reform on its own is not the panacea to inequitable representation in governance. It will take time before we can reap the benefits of this legislation. However, it is worth implementing and strengthening. Gender quotas require a perceptual shift.

There is need to celebrate the women who against all odds have succeeded in being iconic models as we move towards substantive representation. Those that have had an opportunity to benefit from reserved seats should switch to elective seats and create room for beginners or the novices. 


\section{RECOMMENDATIONS}

The following recommendations are given in this study: Firstly, there is need to have incentives that will help promote gender quota thresholds. Secondly, there is need to have a sectoral approach to Gender and a strategy for balancing between quantity and quality.

\section{Incentives for Gender Quota Thresholds}

From the data presented, it is evident that constitutional change is good is as far as transforming practice is concerned however there is need to come up with other incentives in form of policies that would help women to better take advantage of the gender quota threshold as they should. This is especially in relation to political parties which determine the kind of women nominated. Despite the presence of the Political Parties Act, the process that the parties pursue to arrive at the list of their nominees is nebulous. From the interviews carried out, it was clear that none of the institutions answerable wanted to take responsibility for this gap. These include: IEBC and the Registrar of Political Parties. As one participant said, "we do not meddle in Party activities". One participant mentioned that there is need to have a structure in place whereby those who were nominated last time are able to vie in the next elections. This is appropriate as it would create room for novices. However, the problem is that the nomination process is fuzzy so much so that those nominated in some instances may not have the stamina required to vie in the next elections.

\section{Sectoral Approach to Gender}

The fact that funding for the Gender Departments and Gender Committees in the County Governments is limited means that peoples mindsets around gender is very different. As mentioned earlier, there was very little set aside for these Departments therefore the way forward would be to have a sectoral approach to gender in the Counties. This means that gender aspects are mainstreamed in all the sectors as opposed to having a Gender Department that seeks to address gender issues on its own. This means consciously incorporating gender in all sectors and this theoretically means that we are moving beyond reversing gender trends to displacement and transformation in each sector (Verloo and Lombardo, 2007). Secondly, there is need to have gender responsive budgeting at the County level to ensure that the gender issues in the different sectors are addressed.

\section{Strategy for balancing between Quantity and Quality}

There is also need to have an affirmative action strategy that goes beyond the numbers to empowering the women wholesomely, i.e. maintaining a balance between quantity and quality as numbers alone point to descriptive representation. However, there is need to move towards substantive representation whereby women in governance defend gender issues collectively (Galito, 2018). Although the numbers are good and they have been demystified, it's important to have other incentives to propel this legislation as we also look into how to ensure that the numbers are not vacillating. This involves empowering women at an early age and organizing for mentors for them. The flip side to this is that according to some scholars, it's possible to have a few women who are well able to push for policy transformation but in our context numbers are important especially when voting in the Assemblies. Besides, there are other legal gains that are hinged on the gender quota threshold such as land rights. Therefore the need to guard and protect this legislation.

\section{References}

Banerjee-Hamadeh, L. (2000). Think globally, Elect Locally? In United Nations Development Programme: Women's Political Participation and Good Governance: $21^{\text {st }}$ Century Challenges.

Braga, M. \& Scervini, F. (2015). The Perfomance of Politicians. The Effect of Gender Quotas. Societa italiana di economia pubblica, Working Paper No 701 dicembre 2015. 
Brody, A. (2009). Gender and Governance. Overview Report. BRIDGE, Institute of Development Studies.

Brody, A; Burnley, J \& Phyu, P. (2016) Political Gender Quotas. Key Debates and Values for Myanmar. Discussion Paper.

Chen, L. (2010). Do Gender Quotas Influence Women's Representation and Policies? The European Journal of Comparative Economics, Vol 7, no 1, 13-60. http://eaces.liuc.it

Creswell, J.W. (2014). Research Design: Qualitative, Quantitative and Mixed Methods Approaches (4ed.) International Student Edition. New Delhi: Sage.

Dahlerup, D. (1988). From a Small to a Large Minority: Women in Scandinavian Politics. Scandinavian Political Studies, 11(4), 275-297.

Dahlerup, D. \& Freidenvall, L. (2010). Judging Gender Quotas: Predictions and Results. Policy and Politics, 38 (3) 407-425.

Domingo, P., McCullough, A.,Simbiri, F. \& Wanjala, B. (2016). Women and Power: Shaping the development of Kenya's 2010 Constitution. Overseas Development Institute Report.

Franceschet, S., Krook, M. L., \& Piscopo, J. M. (2009). The Impact of Gender Quotas: A Research Agenda. Paper presented at the Annual Meeting of the American Political Science Association, Toronto, Canada, September 3-6, 2009.

Galito, M. S. (2018). Women in Politics- Portugal as a Case Study. Working Paper CEsA 173/2018.

Gender Alliance for Development Centre (2015). Albanian Women Participation in Politics and Decision-Making. Discussion Paper.

Government of Kenya (2010) The Constitution of Kenya. Nairobi: Government Printers.

Government of Kenya (2012) The County Government Act. Nairobi: National Council for Law Reporting.

Kurebwa, J. (2015). A Review of Hanna Pitkin's (1967) Conception of Women's Political Representation. International Journal of Scientific and Research Publications 5 (2), 50-60.

Mejere, O. (2012). Does gender Matter in Governance? Gender Quotas as a Good Policy Tool: Practice and Failures in Lithuania. Social Research, 2(27), 46-61.

Muiruri, F. (2013). Kenya Doing Badly Compared to Rest of Africa. Status of Women: Kenya Woman. Advocating for the rights of women. Issue Number 37, June 2013. The Open Society Initiative for Eastern Africa.

National Democratic Institute (2010). Democracy and the Challenge of Change. A Guide to Increasing Women's Political Participation.

Nazneen, S. (2018). Gender and Intersecting Inequalities in Local Government in South Asia. IDS Working Paper, Volume 2018, No 507.

Nzomo, M. (2012). Representational Politics in Kenya: The Gender Quota and Beyond. Paper presented and published by Africa Research and Resource Forum, December 2012.

Oruko, I. (2017). Only 96 out of 1450 wards elected women on August 8. Daily Nation, Thursday, August 24 th 2017. Paxton, P. \& Hughes, M. M. (2015). The Increasing Effectiveness of National Gender Quotas 1990-2010. Legislative Studies Quartely, 40(3).

Pitkin, H. F. (1967). The Concept of Representation. Berkeley: University of California Press.

Savin-Baden, M. \& Major, C.H. (2013). Qualitative Research. The Essential Guide to Theory and Practice. London and New York: Routledge.

Shamim, I., \& Kumari, R. (2002). Gender and Local Governance: A New Discourse in Development. A paper submitted to South Asia Network of Economic Research Institutes.

Thomas, T.A. (2016). Remedying Systematic Sex Discrimination with Gender Quotas: 'Just Because'. Harvard Journal of Law and Gender (forthcoming).

Toraasen, M. (2016). Gender Parity and the Symbolic Representation of Women in Senegal. Master's Thesis at the Department of Comparative Politics, University of Bergen.

United Nations (2006). Breaking Barriers: Gender Perspectives and Empowerment of Women in Least Developed Countries. 
Kilelo, H. K., Kurgat, A., \& Ong'ondo, C. O. (2019). "Where the Shoe Pinches": Impediments to Successful Execution of Gender Quota Thresholds in Kenya. Advances in Social Sciences Research Journal, 6(9) 367-378.

United Nations (2016). The Sustainable Development Goals Report. Unstats.un.org/sdgs/report/2016/The Sustainable Development Goals Report 2016.pdf

United Nations Human Settlements Programme (2008) Gender in Local Government: A Sourcebook for Trainers. UN WOMEN (2013). Gender Checklist Handbook for County Governments in Kenya.

Wang, V. \& Yoon, M. Y. (2018). Switches from quota-to non-quota seats: A Comparative Study of Tanzania and Uganda. (CMI Brief No. 2).

White, T.J.\& Mariani, M. (2015). Gendered Interest and Ambition: Quotas and Challenges to Achieving Greater Female Representation in Ireland. The Canadian Journal of Irish Studies, 39 (1),206-223.

www.quotaproject.org 